\title{
The Effects of Guided Inquiry and Modified Free Inquiry Learning Models on Students' Higher Order Thinking Skills for the Topic of Human Respiratory System at SMA Negeri 1 Labuhan Deli
}

\author{
Nur Atikah $^{1}$, Ely Djulia ${ }^{2}$, Melva Silitonga $^{3}$ \\ Postgraduate Program, Universitas Negeri Medan \\ Department of Biology Education \\ North Sumatera, Indonesian \\ Corresponding email: nuratikah.1702@gmail.com
}

\author{
Nur Atikah $^{1}$, Ely Djulia ${ }^{2}$, Melva Silitonga ${ }^{3}$ \\ Postgraduate Program, Universitas Negeri Medan \\ Department of Biology Education \\ North Sumatera, Indonesian \\ Corresponding email: nuratikah.1702@gmail.com
}

\begin{abstract}
The aims of this quasi experiment research were to determine the differences of students' higher order thinking skills about the topic of human respiratory system using the guided inquiry (GI) and modified free inquiry (MFI) learning models at SMA 1 Labuhan Deli. The population of this study were all students of class XI MIA at SMA Negeri 1 Labuhan Deli of the academic year 2016/2017, amounting to 90 students consisting of 3 classes each of 30 students. The sample was taken in total, namely the class $\mathrm{XI} \mathrm{MIA}_{3}$ was applied by the GI learning model, class XI $\mathrm{MIA}_{2}$ was applied by the MFI learning model and class XI MIA $A_{1}$ was applied by conventional learning model. The research design used was pretest-posttest control group design. Pretests were given before the learning models would be applied while post-tests were given after the instruction ended. The research instrument consisted of 12-higher order thinking ability essay test items according to Bloom's Taxonomy, containing the items of analysis (C4), evaluation (C5) and creation (C6). Data were analyzed by covariate analysis technique (ANCOVA) followed by Tukey's test with a significant level of $\alpha=0.05$. The results of ANCOVA showed that there were significant effects of learning models (GI, MFI and conventional) on students' higher order thinking skills $(F=5.845 ; P=0.004)$. The results of Tukey's showed that students' higher order thinking skills taught by the GI learning model were significantly different from the MFI and conventional learning models. The students' higher order thinking skills who were taught by GI learning model (78 \pm 7.95$)$ higher than the MFI learning model (71.67 \pm 7.52$)$ and conventional learning model $(73.07 \pm 7.11)$. The findings of this study implied the importance of the inquiry model to be applied in Biology learning to improve the higher order thinking skills of high school students.
\end{abstract}

Keywords-Guided Inquiry; Modified Free Inquiry; Higher Order Thinking Skills.

\section{INTRODUCTION}

Education plays an important role to improve the quality of human resources (HR) in ensuring the sustainability of the development of a nation, especially in the face of the era of global competition. Therefore, the development of the education sector must be a priority to produce human beings who are qualified and able to compete, in addition to having noble character and good norms.

Teaching and learning activities are the most basic activities in the education process, whether or not the achievement of educational goals is successful depends a lot on the learning process experienced by students. Biology as part of science requires learning competence in the realm of high-level understanding and high-level thinking is an important factor in the world of education, but students tend to memorize rather than understand where the child's brain is constantly accustomed to remembering and hoarding information without being required to relate it to daily life, even though understanding is the basic capital for subsequent mastery. As a result, students' high level of thinking ability is difficult to develop.

The commitment to improve high order thinking in developed countries is increasing, while conceptual knowledge tends to be reduced (Nur, 2012). This is different from in Indonesia, which still emphasizes the concept of knowledge not high-level thinking, there are some obstacles to the development of high-level thinking students, one of which is that students are not given the opportunity to observe or experiment, students are crammed with concepts without any scientific process to find the concept, and more student performance appraisal systems are based on tests that test lowlevel cognitive abilities.

High-level thinking skills play an important role in increasing students' reasoning (Sembiring, 2008). Educators regard higher-order thinking skills as high-level thinking that occurs when students acquire new knowledge and store it in their memories, so this knowledge is correlated, organized, or evaluated to achieve certain goals. These skills must include sub-skills such as analysis, synthesis and evaluation, which are the highest levels in Bloom's cognitive taxonomy. Students are 
said to be thinking high level if they can show their performance in understanding at a higher level of ability, both in the same context and in different contexts.

The same problem is also found in SMA Negeri 1 Labuhan Deli where the learning of Biology conducted by the teacher now emphasizes more on the domain of Bloom knowledge (C1) and understanding (C2). In the Bloom domain application (C3), analysis (C4) has also been done but, synthesis (C5) and evaluation (C6) are rarely applied in learning, as a result students are less trained to develop their reasoning power in solving problems and applying concepts that have been learned in everyday life.

One of the learning that is expected to be able to overcome these problems is inquiry learning, namely a student-centered learning model, which is able to enable students to maximally search for and discover the core subject matter themselves, generate discussion, and improve students' high-level thinking skills. The stage of inquiry learning consists of observation, formulating problems, formulating hypotheses, designing experiments, collecting data, analyzing data, and arguing (Joyce et al., 2009).

Zion (2007) stated that inquiry learning models train students in solving problems, increasing understanding of science, developing learning skills in science, and scientific literacy and can train students' thinking skills. According to Satriawati, Ely Djulia, and Hasruddin (2016), inquiry learning models can improve students' high-level thinking skills and also change students' learning conditions so that they are interesting and prefer learning material, motivated and diligent and active and give a deep impression on students' memory in taking lessons.

Likewise Wilson (2010) stated that inquiry based learning can increase students' knowledge and also can improve their ability to argue and provide logical reasons. According to the results of a study by Purba NN, Ely Djulia, Hasruddin (2017), students who were taught with guided discovery models were more motivated and enthusiastic in learning which was seen from their readiness, activity and good collaboration in group learning compared to free discovery and conventional learning.

In the Soltis' study (2015), it was also concluded that the use of process-oriented guided inquiry learning strategies (POGIL) as a whole had a positive effect on students' learning outcomes and classroom environment, where he was able to improve high-level thinking skills, and student activity. Margiastuti (2015) suggested that the application of guided inquiry learning models effectively enhances students' understanding of concepts and scientific attitudes on the theme of the ecosystem.

In the guided inquiry learning model the teacher acts as a facilitator and guides students to build knowledge and deep understanding of the subject matter, where students are given the opportunity to work formulating procedures, analyzing results and drawing conclusions independently. The modified free inquiry learning model is a collaboration between guided inquiry learning models and free inquiry. According to Sutopo (2016) the difference between guided inquiry and modified free inquiry is the role of the teacher, in which the teacher guided inquiry model is more dominant in guiding students, while in the modified free inquiry model the teacher only monitors and helps if needed. Likewise Ajwar (2015) modified free inquiry has the characteristic that the teacher restricts giving guidance to students, so that students attempt more independently, so that students can find solutions to problems.

\section{RESEARCH METHOD}

This quasi-experimental research was conducted at SMA Negeri 1 Labuhan Deli, North Sumatra towards the class of XI MIA of first semester in 2016/2017 using the pretest-posttest control group design.

A total of 90 students from 3 classes were taken in total sampling, consisting of class (XI-IA3) as the first experimental class taught using guided inquiry, and class (XIIA2) as the second experimental class taught using modified free inquiry, and class (XI-IA1) as a control class taught using conventional learning. Instruments of 12 items of high-level thinking ability test essays consisting of C4, C5, C6 in human respiratory system material was developed and validated by 2 expert lecturers, both content and construct and tested on 28 students.

Learning takes place during 5 meetings. Classes (1) give a pretest; (2) carry out the learning process with the Guided Inquiry model in class XI MIA 3 , with the model of Modified Free Inquiry in class XI MIA ${ }_{2}$, and with conventional learning in class XI MIA ; (3) post-test; (4) processing data by analyzing the influence of Guided Inquiry model, Modified Free Inquiry and Conventional on students' higher order thinking skills, using ANCOVA techniques; (5) followed by the Tukey's test; then, (6) continued by analyzing the level of students' higher order thinking skills on each indicator.

\section{RESULTS AND DISCUSSION}

From the results of the study, the description of pretest and posttest data on students' higher order thinking skills who were taught by the Guided Inquiry, Modified Free Inquiry and Conventional learning models on the topic of human respiratory system of class XI students at SMA 1 Labuhan Deli can be seen in the table below.

TABLE 1. Results of Pretest and Posttest of the Students' Higher Order Thinking Skills on the Topic of Human Respiratory System of Class XI at SMA Negeri 1 Labuhan Deli

\begin{tabular}{clccc}
\hline $\begin{array}{c}\text { Type of } \\
\text { Test }\end{array}$ & $\begin{array}{c}\text { Learning } \\
\text { Model }\end{array}$ & $\begin{array}{c}\text { Maximum } \\
\text { Score }\end{array}$ & $\begin{array}{c}\text { Minimum } \\
\text { Score }\end{array}$ & Average \\
\hline Pretest & $\begin{array}{l}\text { Guided } \\
\text { Inquiry } \\
\text { Modified Free }\end{array}$ & 72 & 39 & $57,20 \pm 8,79$ \\
& $\begin{array}{l}\text { Inquiry } \\
\text { Direct }\end{array}$ & 73 & 43 & $57,97 \pm 9,27$ \\
& Instruction & 79 & 40 & $61,43 \pm 8,27$ \\
\hline
\end{tabular}




\begin{tabular}{|c|c|c|c|c|}
\hline \multirow[t]{3}{*}{ Posttest } & $\begin{array}{l}\text { Guided } \\
\text { Inquiry }\end{array}$ & 90 & 60 & $78 \pm 7,95$ \\
\hline & $\begin{array}{l}\text { Modified Free } \\
\text { Inquiry }\end{array}$ & 82 & 54 & $71.67 \pm 7,52$ \\
\hline & $\begin{array}{l}\text { Direct } \\
\text { Instruction }\end{array}$ & 86 & 54 & $73,07 \pm 7,11$ \\
\hline
\end{tabular}

The table above showed that the average score of students' higher order thinking posttest which were taught by the guided inquiry obtained an average score and standard deviation (78 \pm 7.95$)$ higher than that of modified free inquiry and conventional learning models, respectively that had obtained an average score and standard deviation of $71.67 \pm 7.52$ ) and $73.07 \pm 7.11)$. The effects of guided inquiry, modified free inquiry and conventional learning models on students' higher order thinking skills that had been analyzed by analysis covariance techniques (ANCOVA) showed the significant influence of guided inquiry, modified free inquiry and conventional learning models on students' higher order thinking skills $(\mathrm{F}=5,845 ; \mathrm{P}=0.004)$.

The results of Tukey's test showed that students' higher order thinking abilities learned by the guided inquiry differ significantly from modified free inquiry $(\mathrm{P}=0,002)$ and conventional learning models $(\mathrm{P}=0,013)$, but higher order thinking abilities learned by the modified free inquiry no different significantly from conventional learning models $(\mathrm{P}=$ 0,474). Students' higher order thinking skills can be considered in Figure 4.1. below.

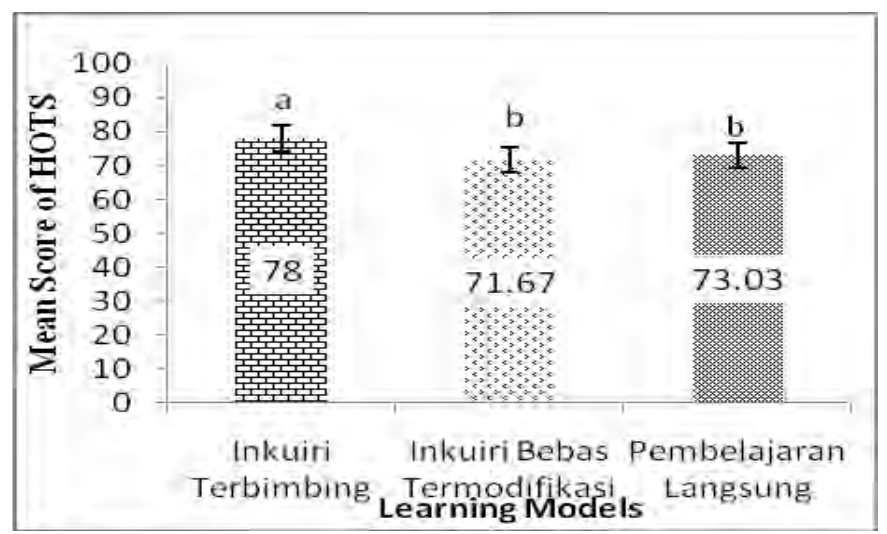

Fig 1. The Effect of Guided Inquiry, Modified Free Inquiry and Conventional Learning Models on Students' Higher Order Thinking Skills on Human Respiratory System Material at SMA Negeri 1 Labuhan Deli. Different letters above diagrams mean that they differ significantly.

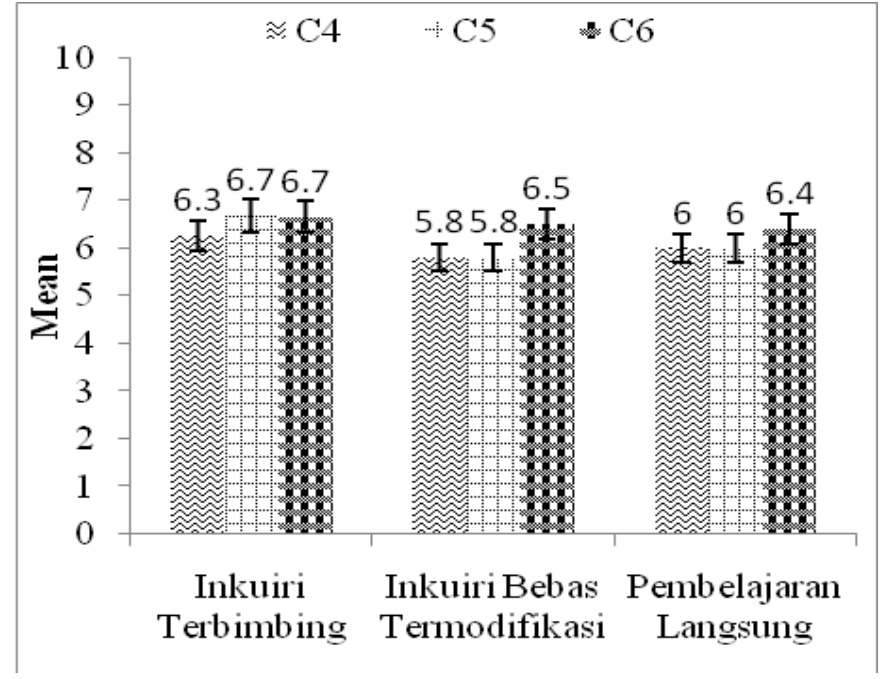

Fig 2. The Effects of Guided Inquiry, Modified Free Inquiry and Conventional Learning Models Based on Bloom's Taxonomy Indicators Anderson and Krathwohl (2001) on Human Respiratory System at SMAN 1 Labuhan Deli.

Based on the data of higher order thinking skills of 30 students of guided inquiry class, the total score of the correct answers in C4 questions was 940 (from a max score of 1200) with an average of 6.3 ; the correct answer to the C5 problem was 801 (from a max score of 960) with an average of 6.7; and the correct answer to C6 obtained a score of 599 (from a max score of 720) with an average of 6.7. This has shown that students' higher order thinking skills using guided inquiry on the criteria of $\mathrm{C} 5$ and $\mathrm{C} 6$ was higher than the criteria for $\mathrm{C} 4$.

While the data of students' higher order thinking skills using the modified free inquiry class, obtained a total score of correct answers to questions C4 is 864 (from a max score of 1200) with an average of 5.8; the answer to the C5 question obtained a score of 698 (from a max score of 960) with an average of 5.8; and answers to questions about C6 obtained a score of 588 (from a max score of 720) with an average of 6.5. This has shown that students' higher order thinking skills by using modified free inquiry on the C6 criteria were higher than $\mathrm{C} 4$ and $\mathrm{C} 5$.

While the data of students' higher order thinking skills on conventional class, obtained the total score of the correct answer about C4 is 894 (from a max score of 1200) with an average of 6.0; the answer to the $\mathrm{C} 5$ question obtained a score of 722 (from a max score of 960) with an average of 6.0; and answers to questions C6 obtained a score of 576 (from a max score of 720) with an average of 6.4. This has shown that students' higher order thinking skills by using modified free inquiry on the $\mathrm{C} 6$ criteria were higher than $\mathrm{C} 4$ and $\mathrm{C} 5$.

On the guided inquiry students can systematically criticize in justifying or giving opinions in solving problems and assessing the right answers to learning material, and in asking questions more leads to causal questions. This is because the guided inquiry helps students gain real experience in learning (Ifeoma \& Ezeoba, 2013). They will be guided to understand and be directly involved with the problem. Students can obtain 
information on learning activities and learn to observe the situation in their environment and research and solve problems in respiration activities, why a person who sleeps can sound snoring while on activities such as running does not produce snoring.

The guided inquiry is superior compared to the modified free inquiry because students still rarely learn to think independently. Guided inquiry is suitable for students who are not accustomed to independent thinking, because by using this learning model students are faced with relevant tasks to be completed either with their group or individually in order to be able to solve problems and draw conclusions independently, such as formulating the causes of abnormalities in the lungs of smokers.

The mean cognitive achievement C4 (analysis); C5 (evaluation) and C6 (depression) class given a guided inquiry is better than the modified free inquiry as well, this is because through guided inquiry, students are more focused on determining problem solving that produces concepts new ones for students, because more directed students will be able to understand the concept better and not experience difficulties in solving problems. This is in line with Umam (2011) in his research, it was concluded that the guided inquiry gives better results than the modified free which was seen from the average student value.

\section{CONCLUSION}

Based on the results of the study and discussion aforementioned can be concluded as follows: there was a very significant difference $(\mathrm{F}=5.845 ; \mathrm{P}=0.004)$ among guided inquiry, free modified inquiry and conventional. With the use of guided inquiry, modified free inquiry and conventional learning models on the topic of human respiratory system towards the students' higher order thinking skills of class XI at SMAN 1 Labuhan Deli. Successively students' higher order thinking skills from the best to the least were students who were taught using guided inquiry, free modified inquiry and conventional learning models, respectively.

\section{REFERENCES}

[1] Nur, M. 2012. Focus Penelitian dan Pengembangan PSMS Unesa. Pusat Sains dan Matematika Sekolah UNESA. Surabaya.

[2] Sembiring, T. 2008. Meningkatkan Kemampuan Berpikir Tingkat Tinggi. Jurnal Epsilon Tekhnik Elektro Unjani. 6 (1).

[3] Joyce. B., Weil. M., Calchoun E. 2009. Models of Teaching Edisi Kedelapan. Yogyakarta: Pustaka Pelajar.

[4] Zion, M. 2007. Implementation Model of an Open Inquiry Curiculum.Science Education International. 18(2): 93-112

[5] Satriawati, Ely. Djulia, Hasruddin. 2016. Pengaruh Penggunaan Media ICT dalam Pembelajaran Inkuiri Topik Bioteknologi Terhadap Kemampuan Berpikir Tingkat Tinggi Siswa MAN 3 Medan. Jurnal Pendidikan Biologi. 5(2): 131-134.

[6] Wilson, C.D., Taylor, J. A., Kowalski, S.M., \& Carlson, J. 2010. The relative effects and equity of inquiry-based and commonplace science teaching on students' knowledge, reasoning, and argumentation. Journal of Research in Science Teaching, 47(3), 276-301.

[7] Purba, N.N., Ely Djulia., Hasruddin. 2017. Pengaruh Penggunaan Model Guided Discovery dan Free Discovery terhadap Pengetahuan Prosedural pada Materi Sistem Pernapasan di Kelas XI SMA Negeri 7 Medan.Prosiding Seminar Nasional III Biologi dan Pembelajarannya.UNIMED.

[8] Soltis, R., Verlinden, N., Kruger, N., Carroll, A., and Trumbo, T. 2015. Process-Oriented Guided Inquiry Learning Strategy Enhances Students' Higher Level Thinking Skills in a Pharmaceutical Sciences Course. American Journal of Pharmaceutical Education 2015. 79(1): 1-8.

[9] Margiastuti, N. M., Parmin., Pamelasari. S. D. 2015. Penerapan Model Guided Inquiry Terhadap Sikap Ilmiah dan Pemahaman Konsep Siswa pada Tema Ekosistem.Unnes Science Education Journal. 4 (3): 10411048

[10] Sutopo., Masykuri, M., dan Cari. 2016. Pembelajaran Fisika dengan Model Inkuiri Terbimbing dan Inkuiri Bebas Termodifikasi Ditinjau dari Kreativitas dan Sikap Ilmiah Siswa. Jurnal Inkuiri. 5(1): 122-132.

[11] Ajwar, M., Adi, B. P., dan Sunarno, W. 2015.Pengaruh Pembelajaran Inkuiri Terbimbing dan Inkuiri Bebas Termodifikasi Terhadap Prestasi Belajar Ditinjau dari Berpikir Kritis dan Kedisiplinan Belajar Siswa Kelas X MIA SMA Negeri 8 Surakarta Tahun Pelajaran 2014/2015.Jurnal Inkuiri. 4 (3): 127-135.

[12] Anderson, L.W., dan Krathwohl, D.R (eds) .2001. A Taxonomy for Learning Teaching and Assesing. A Revesion of Bloom's Taxonomy of Educational Objectives. New York: Longman.

[13] Ifeoma, E. O., and Ezeoba K. O., 2013. Effects of Guided Inquiry Method on Secondary School Students "e Performance in Social Studies Curriculum in Anambra State, Nigeria.British Journal of Education, Society \& Behavioural Science, 3(3):206- 222. 